\title{
Markets for marama beans in southern Africa: Linking sustainable products with sustainable livelihoods
}

\author{
Margarida Faria, Edward Mabaya \& Danie Jordaan ${ }^{1}$
}

Indigenous natural food plants are critical to rural livelihoods, especially in arid and semiarid regions where they contribute significantly to food security and social and economic welfare. The sustainability of these plants is therefore of paramount importance. This paper analyses the market conditions for marama bean (Tylosema esculentum) products, taking into account economic, social and cultural conditions. Information on local livelihoods was gathered through focus groups and in-depth interviews with key informants in Botswana, South Africa and Namibia. The market analysis for the marama products was conducted using the PEST (political, economic, social and technical) analysis framework and structured questionnaires directed at retail outlets. The study found that assuring the sustainability of local people's livelihoods while creating a bigger market is only achievable through community organisations supported by a broad marketing strategy and using cultivated marama.

Keywords: marama; commercialisation; sustainable product; sustainable livelihood

\section{Introduction}

Indigenous natural products are made from plants growing in areas with significant biodiversity, using indigenous knowledge systems. They are an important part of rural people's diet, contributing to their food security and social and economic welfare. Natural products also create new opportunities for poor communities to participate in locally

\footnotetext{
${ }^{1}$ Respectively, Auxiliary researcher, Department of Global Development, Tropical Research Institute, Lisboa, Portugal; Research Associate, Emerging Markets Program, Charles H Dyson School of Applied Economics and Management, Cornell University, Ithaca, New York; and Associate, Department of Agricultural Economics, Extension and Rural Development, University of Pretoria. Corresponding author: danie.jordaan@up.ac.za
} 
generated sustainable development solutions. For example, two species that are indigenous to southern Africa - honeybush tea (Cyclopia spp.) and rooibos tea (Aspalathus linearis) - have been successfully commercialised into global agribusinesses that have benefited many poor communities (Reinten \& Coetzee, 2002). Many of these communities live in arid and semiarid areas where agricultural potential is limited and households have to manage high levels of risk and uncertainty (Scoones \& Chibudu, 1995). Despite this great potential, however, commercial production of traditionally used plants in Africa has been minimal, partly because cultivation methods and strategies for value chain development are not well understood (Mander, 1998).

Projects that deal with indigenous botanical products are usually associated with economically and socially dispossessed groups. Characteristically, the plant source and the local community have had to adapt to the same difficult environmental conditions. This is why, when promoting natural products, development practitioners are concerned about the sustainability of not only the plant source but also the people’s livelihoods.

Carney (1998) observes that: 'A livelihood is sustainable when it can cope with and recover from stresses and shocks and maintain or enhance its capabilities and assets both now and in the future, while not undermining the natural resource base.'

In sub-Saharan dry land areas, food supply and income are uncertain because rainfall is scarce and the climate is highly variable. People are therefore obliged to seek solutions outside their homelands. This situation is aggravated when they are displaced from their original territories because previously communal land is occupied by mining or tourism industries or privatised for commercial farming. Faced with new social and natural environments, and having lost their traditional links with their ancestral territories, these communities become more vulnerable. Too often the policy responses to this situation deal only with the immediate consequences, such as food scarcity. Rarely do they consider raising people's autonomy and creating opportunities for effective and sustainable income earning strategies related to sustainable natural products.

Projects aimed at creating a market from under-utilised natural resources can make an important contribution to poor people's autonomy and welfare. This paper combines sociological and economic approaches to analyse the market conditions for marama bean (Tylosema esculentum) in southern Africa, taking into account both the economic conditions 
and the social and cultural environment. When developing indigenous species there are three important policy concerns: conservation, sustainability, and fair and equitable resource allocation. It is essential that indigenous plants such as the marama bean, sourced from economically disadvantaged communities, are domesticated and commercialised using a conscientious approach that values the conservation of environmental resources, while equitably distributing the wealth generated from these practices. All parties involved must commit themselves to the conservation of biodiversity by, inter alia, applying legal 'best practices' with the collection of any plant species for consumption, and by ensuring that no negative environmental impacts flow from bio-prospecting collaboration (Chennells, 2007).

\section{The marama bean}

The marama bean (Tylosema esculentum) is a long-lived perennial legume species endemic to the Kalahari Desert, the neighbouring sandy regions of Botswana and Namibia, and the northwestern region of South Africa. These plants are well equipped to survive under extreme environmental conditions because they have a large tuber which can access and store water and soil nutrients. Marama II says it is 'an excellent source of good quality protein (3039\%)', 'its oil (35-43\%) is rich in mono- and di-unsaturated fatty acids and contains no cholesterol', and it is 'also a good source of micronutrients such as calcium, iron, zinc, phosphate, magnesium, and B vitamins, including folate'. This source also says 'it has some components that have been shown in other foods to contribute to good health in particular prevention of non-communicable diseases such as cardiovascular diseases, diabetes and some cancers’' (Marama II, [date]).

\section{The Marama II project}

The Marama II project, Development of Innovative and Healthful Marama Bean Products Targeting Niche Markets (2007-2010), was set up by an international and multidisciplinary consortium to develop a market driven approach for creating innovative high quality and healthful food products. The project worked closely with small and medium enterprises in southern Africa to gain knowledge for commercial processing of the marama bean, including factors that affect the product quality. This was achieved by 
- conducting consumer and market studies in southern Africa to investigate the acceptability of marama bean and its products and identify potential target markets;

- $\quad$ optimising post-harvest methods for de-hulling and processing the beans to develop a range of high quality value-added marama-based food products: marama oil, marama texturised protein products, roasted marama nuts and marama milk;

- $\quad$ evaluating the texture, flavour, taste and shelf life during storage of the processed products; and

- $\quad$ evaluating the products' health benefits by investigating anti-microbial activity, immuno-modulatory and physiological activities, antioxidant activity, direct anti-HIV properties, and anti-carcinogenic activity on different cancer cell lines.

Consumer studies based on socioeconomic and anthropological surveys, combined with sensory analysis of prototypes of the new products, were used to define a marketing strategy. This paper provides an anthropological and socioeconomic analysis of living conditions in the so-called 'marama areas', identifies the opportunities for and constraints to the new valueadded marama products, and proposes marketing strategies in the event that the products are considered for commercialisation.

\section{Methodology}

A team of social scientists assisted by local researchers and translators surveyed six rural areas of Botswana, South Africa and Namibia by collecting information from local informants during the marama gathering season (April). In Botswana the fieldwork was done in April 2007 in the regions of Jwaneng and Ghanzi (villages Sese, Naledi, East Hanahai, West Hanahai, Grootlaagte, Qabo and Kagakae); in South Africa it was done in April 2008 in the regions of Lephalale (Marapong township) and Steenbokpan; and in Namibia it was done in Gobabis (villages Sandveld and Epukiro Post 3 and the RC Mission) and in the Okakarara region (villages Okatuuo, Okatjau and Ohamueke). In all the villages focus groups were conducted with around 15 to 20 villagers (mixed groups of men and women) and at least two key informants were interviewed. The survey areas were chosen by the local partners in each country because of the density of marama beans found in the wild in these areas and the 
traditional gathering and use of marama as a staple food. The main goal of the fieldwork was to collect objective information on the current uses and perceived benefits of marama beans and to assess the conditions necessary for cultivating marama as a domesticated crop.

Qualitative methods were selected as a means to understand dynamic processes and social relationships, and handle the complexity and variation observed in local livelihoods. Key informant in-depth interviews were conducted to obtain a deeper understanding of the socioeconomic indicators and the broader social and cultural situation of these communities. In each village the focus groups were composed of a diverse group of individuals representing the community's various ethnic, gender and age groups.

Consumer preference testing for marama products was conducted via structured questionnaires including willingness-to-pay experiments to understand consumers' food consumption patterns, product preferences and buying behaviour. Sensory evaluation was applied to three prototype products: a marama milk product in Botswana ( $n=74)$, a marama fortified sorghum porridge in South Africa $(n=52)$, and marama snack nuts in Namibia $(n=51)$. Descriptive statistics profiling the sample in each country are shown in Table 6.

\section{Socioeconomic and anthropological analysis of the place of marama in the study communities}

\subsection{Communities' food security and cultural identity}

In the rural areas surveyed, gathering wild plants and fruits is an integral part of people's living habits. These wild products are particularly important in times of drought to supplement cultivated products that may be scarce. Besides enhancing food security, gathering wild fruit gives these populations a sense of identity. The San and the Herero were identified as the indigenous groups best acquainted with marama beans; the former because they are hunters and gatherers and the latter because of they are nomads and pastoralists. In the three countries surveyed, villagers said there were more marama available in the past. The decline in availability was ascribed to pervasive drought conditions, to indigenous communities finding it increasingly difficult to access marama, and to structural shifts in land tenure and resettlement policies, resulting in the fencing of land and the subsequent confinement of the area available to the fields around their villages. In Botswana the 
settlements were composed of complex (and sometimes conflicting) inter-ethnic combinations. In post-apartheid South Africa, many black people have moved to peri-urban townships, with limited access to arable land, and away from the areas where marama grows. Only in the Namibian rural areas was it possible to observe a closer relation between the community and natural products, since Herero chiefs, land owners and cattle herders have kept their own lands.

Wild harvesting of marama plants may not be sustainable in the long run. In the Jwaneng area of Botswana, respondents said that in 'old times' (i.e. before independence) the plants were protected by traditional gathering regulations imposed and supervised by the headmen. Today marama seeds are collected before they have time to ripen. These destructive gathering practices are hindering the plant's biological regeneration cycle.

\subsection{Rural consumers' uses}

Despite changes in local people's lifestyles, both where marama beans grow and where they are sold, people recognise marama for their good taste and high nutrient value. Villagers usually roast the dry seeds in hot sand (either in a pot or directly on hot soil beside an open fire). The fresh marama may also be boiled in hot water and eaten like any other legume. The respondents' information about how marama is added to other foods (e.g. pounded as flour or ground into small pieces), showed that it is also an important food supplement which is often compared to meat.

\subsection{Bridging the rural-urban divide}

In southern African countries a high proportion of households rely on income diversification combining natural and economic resources and rural and urban income earning strategies. People living in peri-urban townships still consume marama collected mostly from privately owned fenced fields. This rural-urban interface can be seen as a transition zone, where particular (often risky) activities are described as being unavoidable for the populations' survival.

The urban-rural interface was apparent in the way urban focus group participants showed their connection with their places of origin in the rural areas. Some of these interviewees said they traded some of these natural products in town. They described their urban clients as either people originating from rural areas where marama beans are found or those who had 
acquired a taste for them. This underlines the need to take the complexity of these urban-rural links into account and indicates the potential for selling marama products to urban consumers.

For the populations facing harsher living conditions, marama are largely a subsistence food, a kind of 'life saver' in times of hunger when other foods are not readily available or when they cannot afford to buy food from stores. This is possible because the beans store well. Some informants said that 'when there is nothing, at least there are marama beans'. There is an obvious link between economic stress caused by high rates of unemployment and the resulting poverty and the importance ascribed to these beans.

\subsection{The rural informal market}

Since only small quantities are usually gathered, marama are generally channelled into household consumption, but small- and medium-scale farmers also sell marama, uncooked or roasted, to people in nearby villages or to farm workers (Figure 1). In areas where it is easy to gather marama they do not make much profit as most people already have access to the plants. This informal market for marama is essentially limited to the districts where the plants grow, and are usually not far from the growing areas. The market is dominated by women even when marama is sold outside its growing areas. While marama is sold throughout the year, supply significantly increases in April at the start of the gathering season (Table 1).

In most cases there is a direct relationship between gathering and selling marama, without any intermediaries being involved in the process. Nevertheless, this type of vending implies considerable costs, since poor public transport obliges most vendors to rely on private transport, i.e. by hitching a ride. Street vendors complained that children are no longer available to gather marama because of their school duties. Normally prices are not regulated and there is minimal negotiation. The prices vary somewhat between villages and are determined according to weight (or by using containers such as cups as a standardised volume - see Figure 1). As Table 2 shows, prices also depend on whether the beans are shelled or unshelled, fresh, raw or roasted, and may increase slightly if the beans are sold in neighbouring towns. 
Table 1: Marama beans seasonal chart

\begin{tabular}{|l|c|c|c|c|c|c|c|c|c|c|c|c|}
\hline \multicolumn{1}{|c|}{ Months } & Jan & Feb & Mar & Apr & May & June & July & Aug & Sept & Oct & Nov & Dec \\
\hline Gathered fresh & $\mathbf{x}$ & $\mathbf{x}$ & & & & & & & & & & \\
\hline Gathered dry & & & $\mathbf{x}$ & $\mathbf{x}$ & $\mathbf{x}$ & $\mathbf{x}$ & $\mathbf{x}$ & $\mathbf{x}$ & $\mathbf{x}$ & $\mathbf{x}$ & $\mathbf{x}$ & $\mathbf{x}$ \\
\hline Sold & & & $\mathbf{x}$ & $\mathbf{x}$ & $\mathbf{x}$ & $\mathbf{x}$ & $\mathbf{x}$ & $\mathbf{x}$ & $\mathbf{x}$ & $\mathbf{x}$ & $\mathbf{x}$ & $\mathbf{x}$ \\
\hline
\end{tabular}

Table 2: Marama selling prices in April 2007 (Botswana) and April 2008 (South Africa and Namibia)

\begin{tabular}{|l|c|c|c|c|c|c|}
\hline & \multicolumn{2}{|c|}{ Namibia } & \multicolumn{2}{c|}{ Botswana } & \multicolumn{2}{c|}{ South Africa } \\
\hline Marama & $\begin{array}{c}\text { N\$/cup } \\
\text { (locally) }\end{array}$ & $\begin{array}{c}\text { N\$/cup (in } \\
\text { town) }\end{array}$ & $\begin{array}{c}\text { Pula/cup } \\
\text { (locally) }\end{array}$ & $\begin{array}{c}\text { Pula/cup } \\
\text { (in town) }\end{array}$ & $\begin{array}{c}\text { RD/cup (in } \\
\text { town) }\end{array}$ & RD/litre \\
\hline Ripe (uncooked) & $2.00-3.00$ & - & $3.00-4.00$ & - & - & 6.00 \\
\hline Fresh (uncooked) & - & - & - & - & - & 6.00 \\
\hline Roasted with shell & - & - & 5.00 & - & - & 10.00 \\
\hline Roasted unshelled & 5.00 & 5.50 & $7.00-8.00$ & $5.00-6.00$ & $5.00-6.00$ & - \\
\hline
\end{tabular}

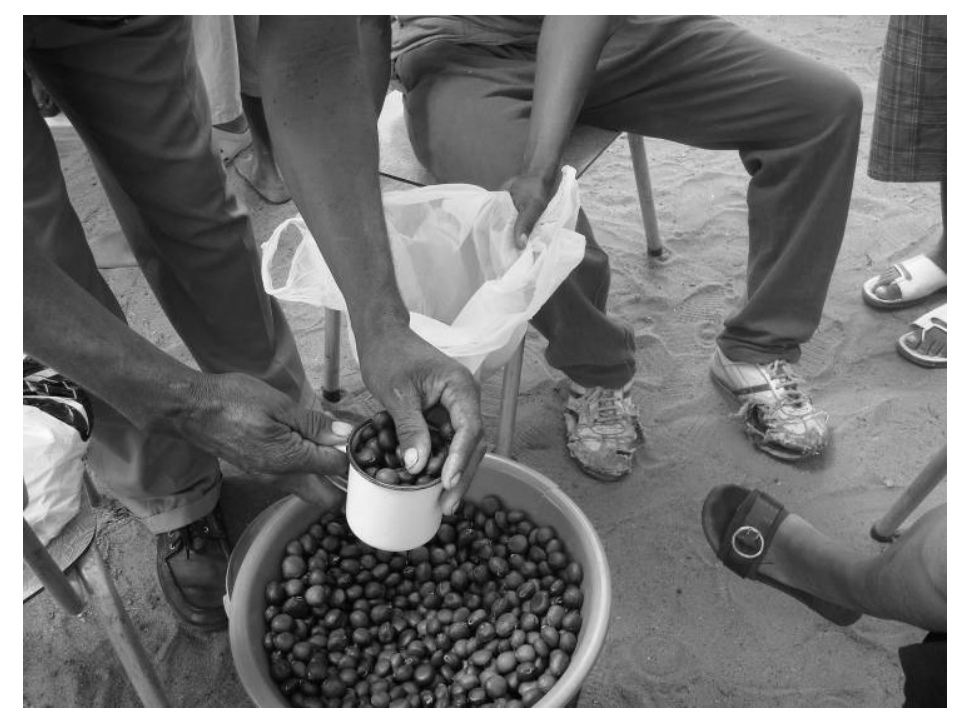

Figure 1 - The beans being sold in Sandveld, Namibia

Table 3, based on Lecup and Nicholson's model for evaluating to evaluate community based tree and forest product enterprises (2000), analyses the marama informal market at community level. 
Table 3: Marama informal market at the community level (field-work results)

\begin{tabular}{|c|c|c|c|}
\hline & Botswana & South Africa & Namibia \\
\hline Market economy & $\begin{array}{l}\text { Lack of raw material. Sold } \\
\text { roasted or raw, surplus } \\
\text { stored. Small quantities } \\
\text { sold to neighbouring } \\
\text { villages and nearest urban } \\
\text { areas (small margins/ } \\
\text { profits). Few vendors, } \\
\text { little competition. Prices } \\
\text { defined by seller, non- or } \\
\text { limited negotiation. } \\
\text { Slightly higher prices in } \\
\text { nearby towns. Problems } \\
\text { with transport. }\end{array}$ & $\begin{array}{l}\text { Raw material supplied by } \\
\text { sellers, who also gather } \\
\text { the beans. Household } \\
\text { consumption or sold } \\
\text { directly to neighbours, not } \\
\text { openly (no street vendors). } \\
\text { Some farm workers sell } \\
\text { outside farming areas. }\end{array}$ & $\begin{array}{l}\text { Raw material supplied by } \\
\text { sellers. Beans gathered by } \\
\text { sellers or children or San } \\
\text { people hired by Herero } \\
\text { farmers. Household } \\
\text { consumption or sold to } \\
\text { neighbouring villages and } \\
\text { nearest urban areas (in } \\
\text { Okakarara by street } \\
\text { vendors). }\end{array}$ \\
\hline $\begin{array}{l}\text { Resource } \\
\text { management/ } \\
\text { Environment }\end{array}$ & $\begin{array}{l}\text { Previously, seasonal } \\
\text { activity. Some rules set by } \\
\text { traditional leaders to } \\
\text { protect marama plants } \\
\text { Now plants being } \\
\text { exhausted near villages, } \\
\text { sustainability at risk. Few } \\
\text { marama in fields due to } \\
\text { drought and land } \\
\text { privatisation. Regulations } \\
\text { needed to protect plants } \\
\text { and local environment. }\end{array}$ & $\begin{array}{l}\text { Plenty of marama beans in } \\
\text { fields in good years } \\
\text { although previously more } \\
\text { plentiful. Some destroyed } \\
\text { by animals - no fences. } \\
\text { Use of land for other crops } \\
\text { has destroyed some plants. } \\
\text { Farmers claim need for } \\
\text { protection. }\end{array}$ & $\begin{array}{l}\text { More marama in the past. } \\
\text { Less now due to drought. } \\
\text { Plenty of marama beans in } \\
\text { the fields in good years. } \\
\text { Fields used to gather } \\
\text { marama and other wild } \\
\text { products, mostly in } \\
\text { communal areas. }\end{array}$ \\
\hline Social/ Institutional & $\begin{array}{l}\text { Gatherers lack legal rights, } \\
\text { must walk long distances } \\
\text { to find high yield marama } \\
\text { plants. Gathering } \\
\text { expeditions becoming rare } \\
\text { - access to fields } \\
\text { increasingly difficult. San } \\
\text { people who previously } \\
\text { gathered now depend on } \\
\text { government food aid. } \\
\text { Most gathering now done } \\
\text { by individuals, mostly } \\
\text { women and children. } \\
\text { Women control the } \\
\text { marama market chain. } \\
\text { Local institutions and } \\
\text { associations not involved. } \\
\text { This could be a } \\
\text { cooperative initiative. }\end{array}$ & $\begin{array}{l}\text { Gatherers lack legal rights. } \\
\text { White farmers eat marama } \\
\text { beans as snack, use farm } \\
\text { workers to gather marama. } \\
\text { Marama areas protected } \\
\text { from intrusion. Access } \\
\text { increasingly difficult for } \\
\text { black population now } \\
\text { living outside farms. Poor } \\
\text { people in townships not } \\
\text { far from 'marama areas' } \\
\text { use marama to alleviate } \\
\text { hunger. }\end{array}$ & $\begin{array}{l}\text { Gathering expeditions } \\
\text { becoming rare. Young } \\
\text { people not interested, } \\
\text { children are at school. In } \\
\text { some cases authorisation } \\
\text { required, since cattle gates } \\
\text { may be left open. On one } \\
\text { farm gatherers were } \\
\text { transported by farm } \\
\text { supervisor to gathering } \\
\text { areas. }\end{array}$ \\
\hline $\begin{array}{l}\text { Science and } \\
\text { technology }\end{array}$ & $\begin{array}{l}\text { Post-harvest operations } \\
\text { limited to storage and } \\
\text { roasting (small quantities). } \\
\text { Only rudimentary skills } \\
\text { needed. No machinery } \\
\text { involved. Oil and body } \\
\text { lotions extracted } \\
\text { (exceptional). Tubers } \\
\text { seldom used. }\end{array}$ & $\begin{array}{l}\text { Post-harvest operations } \\
\text { limited to storage and } \\
\text { roasting. Rudimentary } \\
\text { skills needed. No } \\
\text { machinery involved. }\end{array}$ & $\begin{array}{l}\text { Post-harvest operations: } \\
\text { limited to storage and } \\
\text { roasting. Only rudimentary } \\
\text { skills needed. No machinery } \\
\text { involved. Oil extracted by } \\
\text { San people. Tubers seldom } \\
\text { used. }\end{array}$ \\
\hline
\end{tabular}

Source: Lecup (2000) 


\subsection{Marama domestication and cultivation}

Since the supply of marama in the wild is limited and possibly declining, cultivation is the sole strategy to ensure that sustainable quantities of raw material are produced to reliably feed into a commercial value chain. Cultivation is also important to ensure the continued existence of marama in the wild and prevent over utilisation.

The first attempt at cultivating marama was by a group of women from Botswana who formed the Thusano Lefatsheng club in 1984 and started testing the cultivation of morula fruit, morula kernels, marama tubers and marama beans (Seatini, 2005). The group organised the cultivation, harvesting, purchasing, processing and marketing of these indigenous plants, providing employment for women. By 1989 there were 1500 harvesters and 10 processors, mostly from very poor areas. The products were marketed through local markets in Gaborone and nearby areas.

In the Ghanzi region of Botswana, attempts at cultivation were made on a very small scale in the 1990s in two villages, Grootlagte and West Hanahai, with the help of an NGO called KURU. Marama were also cultivated at Sandveld Research Station in Namibia, but without tangible results. According to key informants in both countries, the cultivated plots were under-supervised and not properly fenced, and local people did not understand the reasons for the projects and therefore failed to appreciate their value. Various difficulties were mentioned. In some villages the soil was considered too sandy to cultivate marama. Marama domestication was seen as very labour intensive since the plant requires continual weeding. Water availability was considered a major constraint. And finally the slow growth cycle of the plant and its low yields were considered problematic, given that this is a food crop and poor people are generally anxious to see quick results. The current prevalence of casual employment replacing long term work has created a culture in which people expect payment immediately on completion of the task at hand. Gathering marama in the wild provides instant cash and thus may be preferred to domestication. It also needs to be mentioned that growing demands for natural products may generate increasing competition for use of land and could lead to conflict (Mabaya et. al., 2009).

A number of research projects (see Table 4) have focused on the agronomic aspects of producing marama because of its perceived potential for improvement, cultivation and commercialisation. Assessments have been made of genetic variation in marama populations 
as a basis for marama improvement in Botswana (Monaghan, 1993), the effects of different dormancy-breaking treatments on the germination and emergence of marama bean (Lebutswe et al., 2003), and the response of marama bean to phosphorous and nitrogen fertilisation in a sandy loam soil (Lebutswe et al., 2003). These three studies point to the challenges and complexities in cultivating the wild varieties of marama. Despite the difficulties, however, a number of key informants in the three countries considered marama cultivation worth trying, although supervision and specialised advice were considered to be crucial.

\section{Table 4: Recent research on the cultivation of marama}

\begin{tabular}{|l|l|l|}
\hline Date & \multicolumn{1}{|c|}{ Title } & \multicolumn{1}{|c|}{ Author } \\
\hline 2007 & $\begin{array}{l}\text { Germination and emergence of the hard seed coated Tylosema esculentum (Burch) } \\
\text { A. Schreib in response to different pre-sowing seed treatments. }\end{array}$ & Travlos, IS \\
\hline 2005 & Systematic studies in Tylosema (Leguminosae). & Castro, S \\
\hline 2002 & Functional heterostyly in Tylosema esculentum (Caesalpinioideae). & Hartley, ML \\
\hline 1999 & $\begin{array}{l}\text { Assessment of symbiont nitrogen nutrition in Marama bean (Tylosema esculentum } \\
\text { L.), a tuber-producing underutilised African grain legume. }\end{array}$ & Dakora, FD \\
\hline 1987 & Marama bean (Tylosema esculentum, Fabaceae) seed crop in Texas. & Powell, AM \\
\hline 1985 & $\begin{array}{l}\text { Potential for the in vitro propagation of a number of economically important plant } \\
\text { for arid areas. }\end{array}$ & Woods, A \\
\hline 1985 & Protease inhibitors of the Marama bean. & Starcher, B \\
\hline 1983 & Voeringselle van 'n Tylosema esculentum-stamper. & Coetzer, LA \\
\hline 1981 & $\begin{array}{l}\text { Marama bean of the Kalahari Desert as a potential food crop, with a summary of } \\
\text { current research in Texas. }\end{array}$ & Bousquet, J \\
\hline 1981 & Morfologie van die sporoderm van Tylosema esculentum en T. fassoglense. & Coetzer, LA \\
\hline
\end{tabular}

Source: US Department of Agriculture (2007)

Land redistribution policies are affecting marama availability. In the Kalahari regions of Botswana and Namibia, continual relocation processes have reduced the availability of land in the areas adjacent to villages. The land is primarily needed to cultivate products providing higher yields, such as sorghum and maize. In Botswana marama grow in areas that have become inaccessible to local populations since the land in question is now mainly allocated to diamond mining, tourism and livestock farming. In South Africa most of the areas where marama grows are also mainly targeted for tourist (safari and game) activities since agricultural activities have progressively been abandoned. The situation is different in Namibia, where much of the land is communal although state owned. 


\section{Building a market for marama products: Opportunities and constraints}

The preceding section evaluated marama production and use in close proximity to the areas where the plant grows in the wild. The immediate focus of any intervention should focus on protecting both the environment and the livelihoods in local communities. However, to scaleup any potential benefits, generate multiplier effects and to ensure economic viability, market opportunities for marama products in local, regional and global markets have to be explored. Table 5 sums up strengths, weaknesses, opportunities and threats involved in developing marama products.

\section{Table 5: Developing marama products at the national level}

\begin{tabular}{|l|l|}
\hline Strengths & $\begin{array}{l}\text { In the rural areas villagers showed readiness to engage in an experimental project and were positive } \\
\text { about generating profits from such a project. } \\
\text { In some rural villages (especially in Namibia) the correlation between developing small processing } \\
\text { industries and an increase in populations' well-being appeared to have some measure of sustainability. } \\
\text { Already existing informal market chains could be further developed. } \\
\text { There is so far no competition, } \\
\text { NGOs are developing projects in some of the surveyed areas and building capacity that could be used } \\
\text { by such a project. } \\
\text { The raw material can be stored and kept in storage (at minimum cost) without deteriorating, and this } \\
\text { overcomes constraints related to seasonality. }\end{array}$ \\
\hline Weaknesses & $\begin{array}{l}\text { Risk of lack of raw material in particular bad (climacteric) years. } \\
\text { Bad road conditions may prevent marama products reaching other regions. } \\
\text { Bad telecommunications channels. }\end{array}$ \\
\hline Opportunities & $\begin{array}{l}\text { Create employment for marama gatherers amongst the poorer communities. } \\
\text { Create employment for women. } \\
\text { Local consumers' uses of marama as a food supplement mixed with other foods (e.g. porridges) are a } \\
\text { good opportunity to try diverse products. } \\
\text { Marama products will enhance food security and improve nutritive content of food. }\end{array}$ \\
\hline Threats & $\begin{array}{l}\text { There is a risk that ethnic and social differences may increase and the benefits will not reach the very } \\
\text { poor (e.g. the San). } \\
\text { Marama may become a cash crop instead of a nutritive food in the areas where the project will be } \\
\text { implemented. } \\
\text { The project as a whole may not be sustainable if there skills and supervision are insufficient. }\end{array}$ \\
\hline
\end{tabular}

\subsection{Local perspectives on marama markets}

A pertinent question with regard to commercialising marama is how income benefits derived from marama products will reach the communities that are both culturally attached to the product and economically vulnerable. It was apparent from the fieldwork that most communities that still gather marama are living in remote areas and undergoing a stressful process of social and cultural adaptation to multi-ethnic communities. In addition, these communities are weak in social capital (e.g. social resources such as individual networks, 
relationships of trust, and access to wider institutions in society) and natural capital (e.g. land, water, wildlife, biodiversity and environmental resources).

Before the prototype products were developed, traditional consumers of marama were surveyed to ascertain the traditional ways of consuming marama and to test their opinion of potential value-added products. Rural respondents said marama butter and marama biscuits could perhaps be produced at the local level, although no one had ever tried making these. Only marama oil was mentioned as a product, locally made, with a variety of uses (for cooking and for skin care). Most urban respondents supported the development of a different set of products, including butter, oil, milk and fortified flour. Peanuts seemed to come to mind when urban respondents were asked to suggest ideas for marama products (marama butter, marama snacks, marama paste). High prices were nevertheless considered to be a constraint to regular consumption. Yet knowing that the benefits would go to the poorer areas was valued as a strong reason to buy these products, especially if they would be labelled as 'natural'. Products such as marama butter and marama flour were the ones considered most effective for improving poor people's livelihoods as they could be easily mixed with other foods.

Respondents agreed that the marketing of marama products should emphasise:

- their nutritious, healthy and organic value,

- their national origin, and

- helping to sustain indigenous livelihoods.

Consumers also suggested that it would be beneficial to conclude market agreements with neighbouring countries (i.e. South Africa and Namibia), since this would encourage competition and promote the diversity of marama products. Focus group participants agreed that the products should fit into people’s lifestyles.

\subsection{Consumer preferences and willingness to pay for marama products}

Analysis of the marketing environment, consumer attitudes towards processed products, and the development of the marketing mix are key considerations when developing indigenous fruit markets (Haq et al., 2008). Marketing research for the marama prototype products was therefore undertaken to identify primary market segments, evaluate their attractiveness and 
recommend a marketing strategy for each product. Respondents from Botswana, Namibia and South Africa participated in tasting sessions to assess their opinions of marama prototype products. This was followed by in-depth interviews and structured experiments to measure their willingness to pay for different products and identify the factors that trigger a buying decision.

The prototype marama products that were developed and tested in the three countries were:

- Marama milk, developed by the National Food Technology Research Centre and the University of Botswana, comparable to long-life dairy products and soy milk.

- Marama fortified sorghum porridge, developed by the Department of Food Science at the University of Pretoria, comparable to fortified porridge products.

- Marama roasted snack nuts, developed by the Department of Chemistry and Biochemistry at the University of Namibia, comparable to luxury nut products.

Table 6: Summary of consumer demographics for three marama products in three countries

\begin{tabular}{|c|c|c|c|}
\hline & $\begin{array}{c}\text { Marama milk } \\
\text { Botswana } \\
\text { n=74 }\end{array}$ & $\begin{array}{c}\text { Fortified porridge } \\
\text { South Africa } \\
\mathbf{n}=52\end{array}$ & $\begin{array}{c}\text { Marama snacks } \\
\text { Namibia } \\
n=51\end{array}$ \\
\hline \begin{tabular}{cl}
\multicolumn{2}{l}{ Gender } \\
$-\quad$ Male \\
$-\quad$ Female \\
\end{tabular} & $\begin{array}{l}26 \% \\
74 \% \\
\end{array}$ & $\begin{array}{l}58 \% \\
42 \% \\
\end{array}$ & $\begin{array}{l}47 \% \\
53 \% \\
\end{array}$ \\
\hline $\begin{array}{cc}\text { Place of residence } \\
-\quad \text { Urban } \\
-\quad \text { Rural } \\
\end{array}$ & $\begin{array}{l}86 \% \\
14 \%\end{array}$ & $\begin{array}{l}81 \% \\
14 \%\end{array}$ & $\begin{array}{l}75 \% \\
25 \% \\
\end{array}$ \\
\hline $\begin{array}{cl}\text { Level of education } \\
\text { - } & \text { Secondary } \\
- & \text { Diploma } \\
\text { - } & \text { Undergraduate } \\
\text { - } & \text { Postgraduate }\end{array}$ & $\begin{array}{c}62 \% \\
5 \% \\
19 \% \\
14 \%\end{array}$ & $\begin{array}{c}54 \% \\
6 \% \\
38 \% \\
2 \%\end{array}$ & $\begin{array}{c}59 \% \\
18 \% \\
20 \% \\
3 \%\end{array}$ \\
\hline \begin{tabular}{cl}
\multicolumn{2}{l}{ Income } \\
- & Low income \\
- & Middle income \\
- & High income
\end{tabular} & $\begin{array}{l}39 \% \\
28 \% \\
33 \%\end{array}$ & $\begin{array}{l}62 \% \\
10 \% \\
28 \%\end{array}$ & $\begin{array}{l}50 \% \\
30 \% \\
20 \%\end{array}$ \\
\hline $\begin{aligned} \text { Age } & \\
\text { - } & \text { Min } \\
\text { - } & \text { Max } \\
\text { - } & \text { Mean } \\
\text { - } & \text { Mode }\end{aligned}$ & $\begin{array}{c}17 \text { years } \\
64 \text { years } \\
26.58 \text { years } \\
22 \text { years }\end{array}$ & $\begin{array}{l}18 \text { years } \\
24 \text { years } \\
21.07 \text { years } \\
21 \text { years }\end{array}$ & $\begin{array}{l}18 \text { years } \\
49 \text { years } \\
22.72 \text { years } \\
22 \text { years }\end{array}$ \\
\hline $\begin{array}{cc}\text { Shopping for no. of people } \\
- & \text { Min } \\
- & \text { Max } \\
- & \text { Mean }\end{array}$ & $\begin{array}{c}1 \\
10 \\
4.14\end{array}$ & $\begin{array}{c}1 \\
15 \\
4.12\end{array}$ & $\begin{array}{c}1 \\
20 \\
4.15\end{array}$ \\
\hline
\end{tabular}


In each of the three countries the research partners recruited consumers for the tasting sessions, in-depth interviews and structured questionnaires on the basis that they currently or potentially consume comparable products. Both quantitative and qualitative tools were used to analyse the market potential for the prototype products. The respondents were asked to complete a sensory evaluation of the prototype products and control products. Following the sensory evaluations, interviews and structured experiments were used to determine each consumer's profiles, expenditure patterns, and exposure to and knowledge of similar products from the same market segment. Tables 6 and 7 summarise the demographic profile of the consumers who took part in the exercise.

Table 7: Summary of consumer -xperience and exposure to prototype product categories

\begin{tabular}{|c|c|c|c|}
\hline & $\begin{array}{c}\text { Long life milk } \\
\text { Botswana } \\
\text { n=74 }\end{array}$ & $\begin{array}{c}\text { Fortified } \\
\text { porridge } \\
\text { South Africa } \\
\mathbf{n}=52\end{array}$ & $\begin{array}{c}\text { Snacks } \\
\text { Namibia } \\
n=51\end{array}$ \\
\hline $\begin{array}{cl}\text { Spend/month on product } \\
- & \text { Min } \\
- & \text { Max } \\
- & \text { Mean }\end{array}$ & $\begin{array}{c}\text { P10 } \\
\text { P800 } \\
\text { P110.71 }\end{array}$ & $\begin{array}{c}\text { R0 } \\
\text { R250 } \\
\text { R68.71 }\end{array}$ & $\begin{array}{c}\mathrm{N} \$ 0 \\
\mathrm{~N} \$ 300 \\
\mathrm{~N} \$ 24.42\end{array}$ \\
\hline $\begin{array}{l}\text { Seen/heard about type of } \\
\text { product } \\
-\quad \text { Yes } \\
-\quad \text { No }\end{array}$ & $\begin{array}{c}99 \% \\
1 \%\end{array}$ & $\begin{array}{l}37 \% \\
63 \%\end{array}$ & $\begin{array}{c}99 \% \\
1 \%\end{array}$ \\
\hline $\begin{array}{c}\text { Bought type of product } \\
-\quad \text { Yes } \\
-\quad \text { No }\end{array}$ & $\begin{array}{c}99 \% \\
1 \%\end{array}$ & $\begin{array}{l}33 \% \\
67 \%\end{array}$ & $\begin{array}{c}99 \% \\
1 \%\end{array}$ \\
\hline Purchased product & $\begin{array}{c}\text { Only dairy } 92 \% \\
\text { Only soy } 0 \% \\
\text { Combination } 8 \%\end{array}$ & $\begin{array}{c}\text { Maize } 40 \% \\
\text { Sorghum } 10 \% \\
\text { Oats } 33 \% \\
\text { Wheat } 17 \% \\
\end{array}$ & $\begin{array}{c}\text { Only dairy } 92 \% \\
\text { Only soy } 0 \% \\
\text { Combination } 8 \%\end{array}$ \\
\hline $\begin{array}{cl}\text { Frequency of purchase } \\
- & \text { Annually } \\
- & \text { Six monthly } \\
- & \text { Monthly } \\
- & \text { Weekly }\end{array}$ & $\begin{array}{l}0 \% \\
7 \% \\
43 \% \\
51 \%\end{array}$ & $\begin{array}{c}8 \% \\
8 \% \\
79 \% \\
6 \%\end{array}$ & $\begin{array}{l}0 \% \\
7 \% \\
43 \% \\
51 \%\end{array}$ \\
\hline $\begin{array}{l}\text { Have heard about health } \\
\text { benefits } \\
-\quad \text { Yes } \\
-\quad \text { No }\end{array}$ & $\begin{array}{l}40 \% \\
60 \%\end{array}$ & $\begin{array}{l}46 \% \\
54 \%\end{array}$ & $\begin{array}{l}40 \% \\
60 \%\end{array}$ \\
\hline Significant health benefits & $\begin{array}{l}\text { High in protein } 50 \% \\
\text { Low in cholesterol } \\
27 \% \\
\text { Lactose free } 12 \% \\
\text { High in fibre } 9 \% \\
\text { High in isoflavones } \\
\quad 2 \%\end{array}$ & $\begin{array}{l}\text { High in energy } 27 \% \\
\text { High in fibre } 25 \% \\
\text { High in protein } 21 \% \\
\text { High in vita \& min } \\
21 \% \\
\text { Low in cholesterol } \\
\quad 16 \% \\
\text { Lactose free } 1 \% \\
\text { Gluten free } 1 \%\end{array}$ & $\begin{array}{l}\text { High in protein } 53 \% \\
\text { High in unsaturated fat } \\
\quad 26 \% \\
\text { Low in cholesterol } 18 \% \\
\text { High in sterols 6\% } \\
\text { High in antioxidants } 4 \%\end{array}$ \\
\hline
\end{tabular}


The responses per prototype product are summarised below:

Marama milk - Most respondents were familiar with long-life dairy milk and bought it weekly or monthly, spending on average P110 per month. Few bought soy milk. Only a few were aware of its health benefits, identifying high protein and low cholesterol as the primary benefits.

Marama fortified sorghum porridge - The respondents were familiar with a variety of fortified porridges, especially maize and oats, bought porridge products monthly, spending on average R70 per month. Only a few were aware of the health benefits of fortified porridge products, identifying high energy and high fibre as the primary health benefits.

Marama roasted snack nuts -The respondents were familiar with a variety of snack products, especially peanuts or a variety of luxury nuts. They rarely bought snack products, but when they did it was on a monthly or six monthly basis, spending on average R28 per month. a fair number were aware of the health benefits of snack nut products, identifying high levels of protein and unsaturated fats as the primary health benefits.

Using the contingent valuation method, the respondents' willingness to pay for the prototypes was compared to their willingness to pay for similar products. The analysis revealed varying levels of willingness to pay for each of the prototype products (see Figure 4). Comparing marama milk with soya milk, $80 \%$ of the respondents were willing to pay the same price or less for the marama product; comparing marama fortified sorghum porridge with other similar fortified porridges, $73 \%$ of the respondents were willing to pay the same price or a little more for the marama product; and comparing roasted marama 'nuts' with other snack nuts, $90 \%$ of the respondents were willing to pay the same price or less for the marama product.

The respondents' limited willingness to pay for marama products raises concerns about the commercial viability of marama cultivation. Further investigation will be required, especially in the absence of a 'novelty premium' for marama products. However, it is important to note that the low level of willingness to pay is typical of consumers' response to most new food products before the launch of any marketing efforts. 


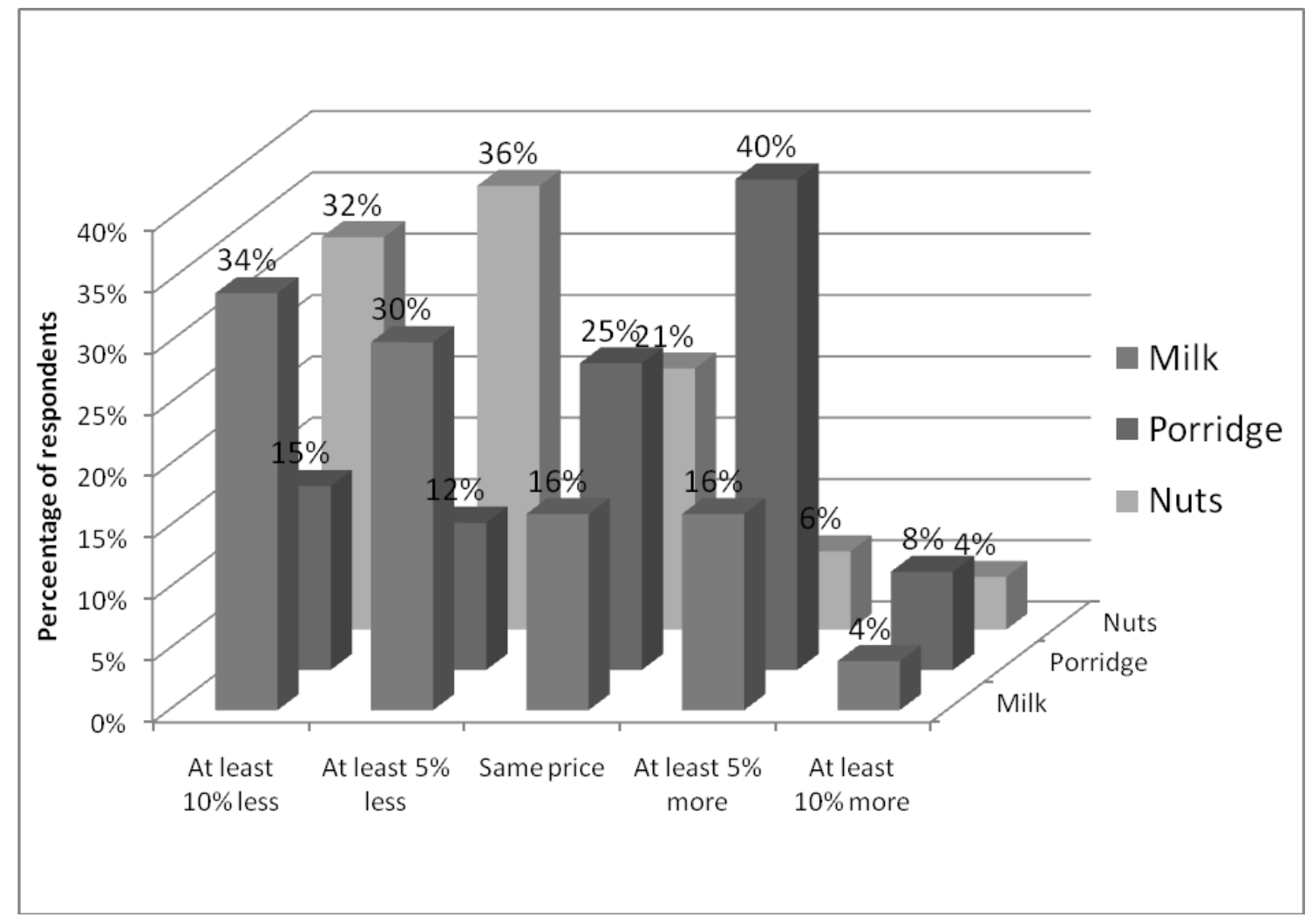

Figure 2: Consumer willingness to pay for marama products

\subsection{Developing value chains}

The International Fund for Agricultural Development emphasises the necessity of developing value chains for natural products during the process of commercialisation (IFAD, 2010). The purpose of these value chains is to create economic opportunities for poor rural communities who are the custodians of natural resources by linking them to markets for the plant products. Haq et al. (2008) argue that the commercialisation of indigenous resources requires, as a necessary condition, viable processing industries supported by the availability of raw materials, product uniformity and consistency and marketability. It also requires the availability of technology to meet processing and market needs, the necessary machinery and equipment, and adequate and easy access to information and support services such as credit. In the context of commercialising marama products, existing commercial manufacturers of similar products will therefore be key role players. These role players will be central in developing the value chains for marama products by linking rural communities where marama grows to the necessary logistics, processing, distribution and retailing and 
consumption activities to transform the raw material and deliver the desired products to consumers.

\section{Marketing strategies for marama products at local and national levels}

The potential market for products derived from marama in Botswana, Namibia and South Africa is large given the high population in these countries (total of 50 million people). A very large proportion of this population is relatively poor and much of the country's wealth is concentrated among a very small section of the population. Consumers in these countries belong to many different ethnic groups and religions and speak a variety of languages, making the region very diverse socially and culturally.

However, with growing disposable incomes, urbanisation, increasingly formalised markets and growing consumer awareness about health, sustainability and social responsibility in the three countries, the market for niche or speciality products has been growing. This presents opportunities for the commercialisation of new products. Many rural communities where marama is found may also benefit from innovative ways of using marama to improve their nutritional status. This is especially applicable to remote and destitute communities in Botswana and Namibia. Improving the nutritional status of these communities may be preferable to helping them earn an income by marketing the beans for processing and sale in remote niche markets.

Given that it is difficult to decide whether to market marama as a commercial product or develop innovative ways for communities to use it to improve their nutritional status, strategies for marketing marama products in either of these markets were formulated. These products need to have product performance at least similar to competing products in terms of consumer acceptability. Besides the product performance, the differentiating benefits of marama products need to be clearly conveyed to consumers, most of whom are currently not aware familiar with marama and its qualities. They will need to be informed through appropriate product research, advertisement, packaging and promotions.

For the marketing strategy for the marama milk product, we recommend that this product be aimed at the long-life milk category and the health foods (milk replacement) category. The product can be positioned as a non-dairy milk with health benefits similar to soya milk and 
sold through the various formal and informal retail networks in the respective countries. The price of the product should be based on consumer willingness to pay and production costs. The product should be promoted through a variety of marketing channels aimed at reaching target consumers in urban areas.

The marketing strategy for the marama fortified sorghum porridge should position the product either as a commercial fortified product or as a fortified complementary food product in feeding programmes aimed at infants, young children, pregnant and lactating women, and HIV/AIDS patients. As with the milk, the product pricing should be based on consumer willingness to pay and production costs. The product for a feeding scheme should be made available either as a 'recipe' to communities that have direct access to marama beans, to improve the nutritional value of their traditional sorghum porridges, or as a feeding programme product available to vulnerable people at no or very little cost. As with the milk product, the product should be promoted through a variety of channels focusing on the unique benefits and characteristics of the product. The product can be marketed as a healthier, more nutritive porridge, made from local ingredients and with an improved or different taste.

Notwithstanding market opportunities for marama products, the ecological and economic feasibility of creating these products still needs to be determined in conjunction with the economic feasibility of cultivation. Depending on which products are considered commercially viable it is recommended that existing commercial manufacturers of similar products in Botswana, Namibia or South Africa be considered as commercial partners. Such a commercialisation strategy can be facilitated by forming partnerships between existing businesses and the rural communities where the raw material is either collected or cultivated.

\section{Conclusions}

Designing a strategy to change marama production from the collection of naturally occurring plants to cultivated fields presents a number of challenges. Marama is still a highly neglected crop where a lack of knowledge is the major limitation to its domestication and cultivation; whereas wild marama are still part of an informal market system and an important source of food security for rural populations. Consequently a compromise should combine strategies both at product and market levels. Assuring the sustainability of the local market and local populations' livelihoods while creating a commercially viable market were principles that led 
the authors to make the final recommendations. However, these may only be successfully achieved with the involvement of the community organisations at the local level, governed by harvesting and market regulations at the national level. A broad marketing strategy for marama products derived from marama cultivation needs to be constantly updated to meet the changing conditions and maintain competitiveness in the market.

\section{Acknowledgements}

The authors wish to thank their Marama II partners from the Universities of Botswana, Pretoria and Namibia for organising consumer focus group discussions, sensory testing and preference testing; the fieldwork participants in Botswana, South Africa and Namibia; Johan Swanepoel and Herbert Karabo (Sandveld Research Station), Huberta Btibinyane (RC Mission, Gobabis region) and John Katjaita (Okakarara region) for making the fieldwork in the rural areas possible; and the Government of Botswana for permission to conduct this research.

\section{References}

Carney, D, 1998. Implementing the sustainable livelihoods approach. In Carney, D (Ed.), Sustainable Rural Livelihoods: What Contribution Can We Make? DFID (Department for International Development), London.

Chennells, R, 2007. San Hoodia case: A report for GenBenefit (Genomics and Benefit Sharing with Developing Countries). www.uclan.ac.uk/schools/school_of_health/research_projects/files/health_genbenefit_san_ca se.pdf Accessed 16 June 2011.

Haq, N, Bowe, C, Dunsiger, Z, 2008. Challenges to stimulating the adoption and impact of indigenous fruit trees in tropical agriculture. In Akinnifesi, FK, Leakey, RRB, Ajayi, OC, Sileshi, G, Tchoundjeu, Z, Matakala, P \& Kwesiga, FR (Eds), 2008. Indigenous Fruit Trees in the Tropics: Domestication, Utilisation and Commercialisation. CAB International, Wallingford, UK. 
Hitchcock, RK, 2002. We are the first people: Land, natural resources in the central Kalahari, Botswana. Journal of Southern African Studies 28(4),797-811.

IFAD (International Fund for Agricultural Development), 2010. Building value chains for natural products: Linking poor rural women to the global cosmetics market. www.ifad.org/events/lectures/phytotrade/index.htm Accessed 18 August 2010.

Lebutswe, T, Ramolemana, GM, Machacha, S \& Tsopito, C, 2003. Seed dormancy of morama bean (Tylosema esculentum): Germination and emergence of morama bean under different dormancy breaking mechanisms. UNISWA Journal of Agriculture 11, 28-33.

Lecup, I \& Nicholson, K, 2000. Community-based tree and forest product enterprises: Market analysis and development. FAO (Food and Agriculture Organisation of the United Nations) Publication and Multimedia Service, Rome, Italy.

Marama II (unpublished) Technical Annex.

Mabaya, E, Carter, C, Castle, J \& Ruethling, G, 2009. Wild foods: Commercialising natural products to improve rural livelihoods in southern Africa. Unpublished case study. Emerging Markets Programme, Cornell University, Ithaca, NY.

Mander, M, 1998. The marketing of indigenous medicinal plants in South Africa: A case study in KwaZulu-Natal. FAO (Food and Agricultural Organisation of the United Nations), Forest Products Marketing Programme, Rome, Italy.

Monaghan, BG, 1993. Genetic variation in the morama Bean (Tylosema esculentum). Master of Agricultural Science, University of Melbourne.

Reinten, E \& Coetzee, JH, 2002. Commercialisation of South African indigenous crops: Aspects of research and cultivation of products. In Janick, J \& Whipkey, A (Eds), Trends in New Crops and New Uses, ASHS (American Society for Horticultural Science) Press, Alexandria, VA, pp. 76-80.

Seatini, YT, 2005. An Alternative Environment and Development Vision for Southern and Eastern Africa, Southern Agenda on Trade and Environment. IISD-ICTSD (International Institute for Sustainable Development - International Centre for Trade and Sustainable Development), [...] . 
Tandon, Y, 2004. An Alternative Environment and Development Vision for Southern and Eastern Africa, Southern Agenda on Trade and Environment. IISD-ICTSD (International Institute for Sustainable Development - International Centre for Trade and Sustainable Development), In Najam, A, Halle, M and Meléndez-Ortiz, R, (Eds) 2008. Envisioning a Sustainable Development Agenda for Trade and Environment. Palgrave Macmillan, 2007, New York, USA.

Scoones, I \& Chibudu, C, 1995. Hazards and Opportunities: Farming Livelihoods in Dryland Africa, Lessons from Zimbabwe. Zed Books, London. 